\title{
Why is The Detection of DNA Sequences Important?
}

\author{
Abdul M Gbaj* \\ Department of Medicinal Chemistry, Faculty of Pharmacy, University of Tripoli, Libya
}

Received Date: July27, 2018; Published Date: August 08, 2018

*Corresponding author: Abdul M. Gbaj, Associate Professor of Genetics and Biochemistry, University of Tripoli, Libya, Tel: +218913556785;

Fax: +218213405023; E-mail: abdulgbaj1@hotmail.com

\section{Mini Review}

Now that sequencing of the human genome is finished [1,2], much information on the underlying genetic causes of many inherited and acquired diseases has been made available. Many genetic diseases have been found to be the result of a change of a single base pair. These alterations, termed single nucleotide polymorphisms (SNP), may cause changes in the amino acid sequence of important proteins. Some SNPs on the other hand may not cause a change in protein expression but may be close on the chromosome to other unknown deleterious mutations and can thus serve as genetic markers for these.

One example of a disease-causing SNP is the G-A transition at position 20210 in the 3 '-untranslated region of the prothrombin or Factor II gene. Prothrombin is the precursor of the serine protease thrombin, which catalyses the last reaction in the blood clotting cascade, converting fibrinogen to fibrin [3]. Prothrombin is key in the balance between pro-coagulation and anti-coagulation [4]. The presence of the mutation causes an upregulation of 3 '-end processing leading to increased mRNA. This in turn leads to an increase in protein synthesis and prothrombin plasma concentration [5]. The mutation occurs in only $2.3 \%$ of the Caucasian population, but in $6 \%$ of patients with deep vein thrombosis (DVT) and 18\% of those patients with a family history of DVT.

The presence of the mutation was also found to increase the risk of myocardial infarction in young women four-fold: this risk was elevated in the presence of other risk factors (for example, smoking, hypertension, diabetes or obesity). Therefore, methods sensitive to single base pair mutations for the rapid screening of patients' samples to detect these and other disease-causing mutations will be important in their prevention and treatment. Hybridisation analysis, where a short probe oligonucleotide (1520 base pairs) bearing some kind of label is used to identify a DNA or RNA sequence by hybridising to complementary base pairs [6], is one of the most powerful tools for the detection of genetic sequences.

\section{Hybridisation}

In order to detect specific sequences in a complex genome such as that of humans (the haploid genome contains $3 \times 109$ base pairs) such methods of hybridisation analysis must be highly sensitive and selective. The probe oligo used must be able to discriminate between the desired sequence and all other sequences, which may differ from the target by only one base pair, especially in the detection of SNPs. A probe of 20 base pairs has a high probability of occurring only once in the human genome, and a probe of this length will be very selective for the desired target. Shorter sequences have a possibility of occurring more than once in the genome and could thereby produce false positive results.

Once a suitable probe sequence has been chosen, a label must be applied to this so that hybridisation to the target can be detected. The type of label chosen determines the sensitivity of the assay. Therefore, the label should be, amongst other criteria set out below, detectable at a low concentration and give low background signals in the absence of the target.

\section{Labelling Strategies}

Other criteria that make a label suitable for use in DNA analysis are:

i. The label should be easily attached to DNA

ii. It should be stable during storage and under hybridisation conditions

iii. The presence of the label should not interfere with hybridisation

iv. The signal should ideally change upon hybridisation so that separation of bound and unbound probes is unnecessary.

v. The label and method of detection should be compatible with automated analysis so that high throughput screening of a large number of samples can be achieved.

vi. Although no label fulfils all these criteria, the many suitable labelling strategies available can be divided into direct and indirect labels.

\section{References}

1. Roberts L (1987) Agencies vie over human genome project. Science 237(4814): 486-488. 
2. Mapping the human genome (1987) The Lancet 329(8542): 11211122.

3. Poort SR, Rosendaal FR, Reitsma PH, Bertina RM (1996) A common genetic variation in the 3 '-untranslated region of the prothrombin gene is associated with elevated plasma prothrombin levels and an increase in venous thrombosis. Blood 88(10): 3698-3703.

4. Rosendaal FR, Siscovick DS, Schwartz SH, Psaty BM, Raghunathan TE, et al. (1997) A common prothrombin variant (20210 G to A) increases the risk of myocardial infarction in young women. Blood 90(5): 17471750 .

his work is licensed under Creative Commons Attribution 4.0 License DOI: $10.19080 /$ NAPDD.2018.04.555628
5. Gehring NH, Frede U, Neu-Yilik G, Hundsdoefer P, Vetter B, et al. (2001) Increased efficiency of mRNA 3' end formation: a new genetic mechanism contributing to hereditary thrombophilia. Nat Genet. 28(4): 389-392.

6. Strachan T, Read AP (1996) DNA Hybridisation Assays. Human Molecular Genetics. BIOS Scientific Publishing, United Kingdom.

Your next submission with Juniper Publishers will reach you the below assets

- Quality Editorial service

- Swift Peer Review

- Reprints availability

- E-prints Service

- Manuscript Podcast for convenient understanding

- Global attainment for your research

- Manuscript accessibility in different formats

( Pdf, E-pub, Full Text, Audio)

- Unceasing customer service

Track the below URL for one-step submission https://juniperpublishers.com/online-submission.php 